medRxiv preprint doi: https://doi.org/10.1101/2020.07.08.20149153; this version posted July 10, 2020. The copyright holder for this preprint (which was not certified by peer review) is the author/funder, who has granted medRxiv a license to display the preprint in perpetuity.

It is made available under a CC-BY-ND 4.0 International license .

Determinants of disease prevalence and antibiotic consumption for children under five in Nepal: analysis and modelling of Demographic Health Survey data from 2006 to 2016.

Charlotte Zheng (corresponding author) ${ }^{1,3}$, Abilasha Karkey ${ }^{1,4}$, Tianyi Wang ${ }^{5}$, H. Rogier van Doorn ${ }^{1,2}$, Sonia Lewycka $^{1,2}$

${ }^{1}$ Oxford University Clinical Research Unit, Vietnam

${ }^{2}$ Centre for Tropical Medicine and Global Health, Nuffield Department of Medicine, University of Oxford, Oxford, UK

${ }^{3}$ Present address: Clinical Infection Unit, St George's University Hospitals NHS Foundation Trust, Blackshaw Road, London, SW17 0QT

${ }^{4}$ Patan Hospital and the Patan Academy of Health Sciences, Kathmandu, Nepal

${ }^{5}$ Princeton University, New Jersey, USA

\title{
Conflicting interests
}

The authors declare that they have no conflicts of interests 
medRxiv preprint doi: https://doi.org/10.1101/2020.07.08.20149153; this version posted July 10, 2020. The copyright holder for this preprint (which was not certified by peer review) is the author/funder, who has granted medRxiv a license to display the preprint in perpetuity. It is made available under a CC-BY-ND 4.0 International license .

\section{Abstract}

Objectives

Our aims were to examine the geographic, socio-economic and behavioural factors associated with disease and antibiotic consumption in Nepal between 2006 and 2016 and to explore healthcare seeking patterns and the source of antibiotics.

\section{Methods}

Cross-sectional data from children under five in households in Nepal was extracted from the 2006, 2011 and 2016 Demographic Health Surveys (DHS). Univariate and multivariate analyses were carried out to assess the association of disease prevalence and antibiotic use with age, sex, ecological zone, urban/rural location, wealth index, maternal smoking, use of clean fuel, sanitation, nutrition, access to healthcare and vaccinations.

\section{Results}

Prevalence of fever, acute respiratory infection (ARI) and diarrhoea decreased between 2006 and 2016, while the proportion using antibiotics increased. Wealth, use of clean fuel, improved toilet sanitation, nutrition and access to healthcare were associated with reduced rates of disease. Those in the highest wealth index use less antibiotics and antibiotic consumption in rural areas surpassed urban regions over time. Health-seeking from the private sector has overtaken government facilities since 2006 with antibiotics mainly originating from pharmacies and private hospitals. Adherence to WHO recommended antibiotics has reduced over time.

\section{Conclusions}

With rising wealth, there has been a decline in disease prevalence but an increase in antibiotic use with more access to unregulated sources. Understanding antibiotic use and identifying associated behavioural and socio-economic factors may help to inform interventions to reduce inappropriate antibiotic use whilst ensuring access to those who need them. 
medRxiv preprint doi: https://doi.org/10.1101/2020.07.08.20149153; this version posted July 10, 2020. The copyright holder for this preprint (which was not certified by peer review) is the author/funder, who has granted medRxiv a license to display the preprint in perpetuity. It is made available under a CC-BY-ND 4.0 International license .

\section{Background}

Antimicrobial resistance is a global health threat driven by increased and inappropriate use of antibiotics. Antibiotic consumption in low- and middle-income countries (LMICs) is increasing rapidly, converging to rates seen in high-income settings (1). Despite this, relatively little is known about antibiotic use and resistance in these settings due to a lack of surveillance systems, poor regulation and reduced awareness. In particular, there is limited knowledge on community antibiotic use for common childhood infections. Infections such as pneumonia and diarrhoea remain major global burdens of disease in under-fives (U5) (2) and represent a significant driver of antibiotic consumption.

Nepal is a landlocked country in South Asia with a population of around 30 million. It is one of the poorest countries in the world with $21.6 \%$ of the population living below the poverty line in 2018 (3). However the economy is developing rapidly; Kathmandu is the fastest growing metropolitan area in South Asia (4) and the proportion of people living below the poverty line has declined substantially since 2003 (5). The recent increase in population wealth may be partially explained by the authorisation of labour emigration by the Home and Labour ministry in 2011. Those returning from working abroad have been able to afford to move from rural villages to urban areas with greater access to basic necessities. Nepal's ecology is composed of flat lands (terai), hills and mountain areas making delivery and access to healthcare challenging as well as contributing to disease incidence. Natural disasters affect public health and the ability to provide robust healthcare. The terai experienced massive floods in 2012, 2014 and 2017 leading to the spread of communicable diseases as sanitation and clean water supplies were disrupted. The April 2015 earthquake caused widespread devastation in Nepal and major disruption of healthcare infrastructures.

Total under-five mortality in Nepal was estimated at 32 per 1000 live births (globally it was 39 per 1000 live births) in 2018 with pneumonia, neonatal asphyxia and diarrhoeal diseases among the leading causes (6, 7). The majority of healthcare is community based with primary health care centres and community health volunteers serving as the first port of call particularly in hard to reach locations (8). Recent years have seen a substantial increase in the number of private hospitals and clinics in urban areas, likely reflecting the demands of an increasingly wealthy population.

The Global Antibiotic Resistance Partnership situation analysis for Nepal reports that antibiotics are the most frequently prescribed medication, used both prophylactically and therapeutically and can be purchased routinely in the community from pharmacies, drug stores and informal drug sellers (7). There are no antibiotic stewardship guidelines and little education of antibiotic resistance amongst health professionals (7). Literature on the demographic and behavioural determinants of disease and antibiotic use for common childhood illnesses in Nepal is limited.

The Demographic Health Survey (DHS) provides data on the prevalence and management of childhood acute respiratory infection (ARI), diarrhoea and fever and the social, demographic and economic characteristics of the households surveyed. The data has not previously been used to examine determinants of childhood illness and associated antibiotic consumption. This information could inform health policy and methods in rationalising antibiotic use to reduce resistance while ensuring access to those in most need 
medRxiv preprint doi: https://doi.org/10.1101/2020.07.08.20149153; this version posted July 10, 2020. The copyright holder for this preprint (which was not certified by peer review) is the author/funder, who has granted medRxiv a license to display the preprint in perpetuity. It is made available under a CC-BY-ND 4.0 International license .

\section{Aims and objectives}

Our aims were to examine the geographic, socio-economic and behavioural determinants of ARI, fever and diarrhoea; examine antibiotic consumption at the disease and population level; and identify demographic and behavioural determinants of antibiotic consumption. We also wanted to explore healthcare seeking patterns and the source of antibiotics. By analysing data captured between 2006 and 2016, we sought to explore how behaviours have changed over time.

\section{Methods}

\section{Datasets}

Cross-sectional data on living children under five in households in Nepal were extracted from the 2006, 2011 and 2016 DHS surveys through datasets and survey reports. The DHS survey collects data using a stratified 2 stage cluster sampling method. The time frame for data collection was from February to August in 2006, February to June in 2011 and June to January in 2016. This mostly covered the wet seasons (June - August) when febrile and diarrhoeal illnesses usually peak in incidence.

\section{Definitions}

ARI was defined as fast and/or difficulty breathing due to a problem in the chest with or without cough in the 2 weeks preceding the survey. This is concordant with the definition given by the WHO Integrated Management of Childhood Illnesses (IMCI) for pneumonia. Fever (parameters not specified in the survey) and diarrhoea (frequent loose or liquid stools) were defined as occurrence of the symptoms in the last 2 weeks. Dysentery was ascertained as the presence of diarrhoea with bloody stools. Occurrence of these symptoms was based on maternal/care-giver recall. Care seeking was defined by whether the mother sought advice or treatment for the illness from any source. Antibiotic treatment was assessed by asking the mother if the child had taken any drugs during the illness and if so whether this consisted of antibiotic pills, syrups or injections. Rates of antibiotic use were calculated with the total under-five population as the denominator to reflect antibiotic consumption at the population level (see Supplementary table 1 in the appendix for a full list of definitions)

\section{Analysis}

A descriptive analysis was carried out on the survey reports and datasets to identify changes from 2006 to 2016 with regards to demographics, disease prevalence and antibiotic use. The source of antibiotics and appropriate use as per the $\mathrm{IMCl}$ guidelines were also examined. A univariate analysis was performed to evaluate the association of the following variables with disease prevalence and antibiotic use: age, sex, ecological zone, urban/rural location, wealth index, maternal smoking, use of clean fuel, sanitation, nutrition, access to healthcare and vaccinations. The multivariate model adjusted for age, wealth and urban/rural location. Sample weights provided by the DHS data were applied to account for over and under sampling of particular regions, and adjustments were made for clustering of data using Taylor-linearized variance estimation. Data management and analysis was carried out using Stata version SE 12. All data was publicly available and anonymised with ethical approval covered under the original data collection. 
medRxiv preprint doi: https://doi.org/10.1101/2020.07.08.20149153; this version posted July 10, 2020. The copyright holder for this preprint (which was not certified by peer review) is the author/funder, who has granted medRxiv a license to display the preprint in perpetuity. It is made available under a CC-BY-ND 4.0 International license .

\section{Results}

\section{Background characteristics}

5457, 5054 and 4861 children (unweighted data) were included in the 2006, 2011 and 2016 surveys respectively. The background characteristics of the population studied are summarised in Table 1. There were 14 sampling strata for 2016 and 13 for 2006 and 2011 (9-11). Male and female children were equally represented and numbers within each age group were evenly spread across the surveys. The majority of the population sampled lived in the terai region, representative of the general population. The proportion of mothers achieving secondary and higher level education increased from 2006 to 2016. There was a higher representation of urban populations in 2016 which reflects increasing urbanisation and updated urban-rural classifications by the National Population and Housing Census (11).

\section{Prevalence of childhood illness}

Overall, the reported percentage prevalence of disease decreased from $5.9 \%$ to $2.4 \%$ and from $11.9 \%$ to $7.6 \%$ between 2006 and 2016 for ARI and diarrhoea, respectively. Conversely, the reported prevalence of fever increased over this time (Figure 1A). The peak prevalence of illness was in those aged between 6-23 months.

The prevalence of $\mathrm{ARI}$ was highest in the hill areas in all 3 surveys (Figure $1 C$ ). The largest reductions in ARI prevalence were seen in the highest wealth quintiles, particularly for 2011 and 2016 (Figure 1B). Diarrhoea prevalence was lowest in the terai region for 2006, but highest in 2011 and 2016, corresponding to the massive floods in the terai (Figure 1D). On the other hand, there was no difference observed between disease prevalence and urban and rural locations. Higher levels of maternal education were associated with increased reported prevalence of fever in 2006 and 2011, although this effect was not seen in the adjusted analysis for 2011. No association was found for maternal education and prevalence of ARI or diarrhoea (Supplementary Table 3, 5 and Table 2).

In terms of behavioural determinants of disease, clean fuel and improved toilet sanitation were associated with reduced prevalence of ARI and diarrhoea in 2011 and 2016, respectively (Supplementary Table 5 and Table 3). This effect was attenuated in the multivariate analysis for clean fuel. Measles vaccination was associated with reduced rates of diarrhoea in 2006 and 2011, although this was not observed in the adjusted model (Supplementary Table 3 and 5). Wasting (a proxy for nutritional status) was associated with increased rates of fever and diarrhoea. Difficulty accessing healthcare was associated with higher ARI, fever and diarrhoea prevalence in 2016. There was no association found between disease prevalence and maternal smoking, improved water source, and other vaccinations (Table 2).

\section{Antibiotic use}

Despite an overall reduction in ARI and diarrhoea prevalence, the reported antibiotic use increased for all 3 conditions from 2006 to 2016 (Figure 2A). In contrast to urban areas, antibiotic use in rural areas increased during each time interval with 2016 data demonstrating rural antibiotic consumption for $A R I$ and fever surpassing those in urban regions (Figure $2 C$ ). Whilst there is a trend for increasing antibiotic use with 
medRxiv preprint doi: https://doi.org/10.1101/2020.07.08.20149153; this version posted July 10, 2020. The copyright holder for this preprint (which was not certified by peer review) is the author/funder, who has granted medRxiv a license to display the preprint in perpetuity. It is made available under a CC-BY-ND 4.0 International license.

increasing wealth for 2006, the 2016 data suggest a reduction in antibiotic use for the wealthiest quintile, which is particularly marked in ARI (Figure 2B). Antibiotic consumption for diarrhoea was highest in the middle and fourth wealthiest quintiles for diarrhoea in 2016, whilst rates were highest in the wealthiest quintile in 2006 and 2011. Higher levels of maternal education were generally associated with increased antibiotic use, particularly for fever, where the effect was present in all 3 time periods (Table 3 and Supplementary Table 4).

Analysis of behavioural factors demonstrated an association with clean fuel and reduced antibiotic consumption, although this was no longer significant in the multivariate analysis. Under-fives with diarrhoea, receiving the measles vaccine and all basic vaccinations in 2016 , had lower rates of antibiotic consumption. Improved toilet sanitation was associated with reduced antibiotic use, whilst wasting lead to greater antibiotic use. Difficulty in accessing healthcare was associated with less antibiotic use for ARI in 2006, whereas there were higher levels of antibiotic use for fever and diarrhoea in 2016 (Supplementary Table 4, 6 and Table 3).

\section{Health-seeking behaviours}

There was a decrease in the proportion of people seeking care from the public sector from $2006-2016$ for all conditions, whilst the proportion visiting the private sector has steadily increased. The pharmacy remained a predominant healthcare provider. Unregulated facilities, including traditional healers and shopkeepers, make up a minority of the healthcare facilities initially visited (Figure 3A). Accordingly, the source of antibiotics reflected these changes in healthcare seeking behaviour, with the majority of those receiving antibiotics visiting a private sector facility first as opposed to the public sector in previous years. Of note, the majority of antibiotics for diarrhoea appears to be consistently coming from pharmacies since 2006 (Figure 3B).

\section{Inappropriate use of antibiotics}

According to the $\mathrm{IMCl}$ guidelines, children with cough only should not be treated with antibiotics. From 2006 to 2011 , the percentage of under-fives with cough only receiving antibiotics increased from $7 \%(n=15)$ to $12 \%(n=39)$. The figure for 2016 could not be calculated as this question was not asked. Those receiving an IMCI recommended antibiotic, specifically oral co-trimoxazole (before 2014), amoxicillin (after 2014) or IV/IM procaine penicillin, decreased from $99.9 \%(n=68)$ in 2006 to $81.6 \%(n=71)$ in 2011 , and then to $50 \%$ $(\mathrm{n}=24)$ in 2016. The IMCI guidelines stipulate that children with diarrhoea and bloody stools (dysentery) should receive antibiotic therapy. In 2006 and 2011, only $11.5 \%(n=12)$ and $23.1 \%(n=23)$ of children with dysentery received antibiotics, whilst $75 \%$ of children who received antibiotics for diarrhoea did not meet the required indication. Again, this question was omitted in the 2016 questionnaire and could not be evaluated. 
medRxiv preprint doi: https://doi.org/10.1101/2020.07.08.20149153; this version posted July 10, 2020. The copyright holder for this preprint (which was not certified by peer review) is the author/funder, who has granted medRxiv a license to display the preprint in perpetuity. It is made available under a CC-BY-ND 4.0 International license .

\section{Discussion}

From our analysis, the prevalence of ARI and diarrhoea in under-fives in Nepal declined from 2006 onwards, particularly among the highest wealth quintiles. The gap between rich and poor has widened over time, which has been the global trend over the last few decades (12). It is often the case that the wealthiest groups are the first to access new services and treatments. Conversely, overall antibiotic use has been rising, reflecting increasing consumption in the low- and middle-income populations, particularly those based in rural locations. Improved access to healthcare due to economic development and the proliferation of private providers may be driving this. Falling rates of antibiotic use in the wealthier quintiles are likely to reflect concomitant reduction in disease prevalence but may also suggest improvements in maternal education (9-11), leading to increased awareness of antibiotic resistance. Even within a low-income setting, patterns of antibiotic consumption reflect global trends as described by Klein et al (1). This is not necessarily undesirable given poorer populations are often in most need of healthcare but it highlights the need for education and regulation amongst these groups to prevent inappropriate use.

Overall, clean fuel, improved sanitation, measles vaccination and nutrition are associated with reduced disease prevalence and lower antibiotic consumption. These findings emphasise the importance of optimising public health. Clean fuel use reduces indoor air pollution, which is a key contributor of acute and chronic respiratory illness (13). Improved toilet sanitation reduced diarrhoeal illness and antibiotic use but this was not seen with improved water sources, suggesting that the former could be more important in reducing enteric infections by preventing contamination of water sources in the first place. The association between measles vaccination and reduced prevalence in diarrhoea has also been demonstrated in India, Pakistan, Nigeria and the Democratic Republic of Congo (14). Measles vaccination has also been associated with increased child survival unrelated to measles prevention and reduction in hospital admissions for other infections $(15,16)$. Nutrition was consistently associated with reduced illness and antibiotic use in our analysis. The 2017 Global burden of disease study identified wasting as the strongest risk factor for mortality associated with pneumonia (17). Public health policy should therefore make childhood nutrition a priority.

Individuals are increasingly seeking healthcare and thus receiving antibiotics from private facilities, which is reflected by the greater number of private hospitals (364) compared to government hospitals (103) available (8). Analysis of DHS and Service Provision Assessment surveys on eight LMICs by Fink et al similarly found a higher number of under-five attendances and mean antibiotics prescribed at private health facilities versus public ones (18). Care-seeking at pharmacies has always remained high, particularly for diarrhoea. Pharmacies often provide quicker perceived solutions to more minor ailments compared to the opportunity cost of spending time being assessed in the hospital. They are likely to be a significant contributor to inappropriate antibiotic use. A study by Wachter et al. demonstrated that antibiotics were supplied inappropriately by $97 \%$ of surveyed pharmacists in Kathmandu for childhood diarrhoea (19). Simulated client studies carried out in pharmacies in India and Thailand reported inappropriate antibiotic use for diarrhoea of $40 \%$ and $52.2 \%$ respectively $(20,21)$. Reduced adherence to IMCI recommended antibiotics for ARI and dysentery has also been observed in other LMICs. A prospective study by Ragowski 
medRxiv preprint doi: https://doi.org/10.1101/2020.07.08.20149153; this version posted July 10, 2020. The copyright holder for this preprint (which was not certified by peer review) is the author/funder, who has granted medRxiv a license to display the preprint in perpetuity. It is made available under a CC-BY-ND 4.0 International license.

et al examining antibiotic use in children up to 2 years old in eight LMICs in South Asia, Africa and South America noted substantial variation from IMCI recommended antibiotics for ARI and in particular bloody diarrhoea (22). This could be secondary to reduced drug availability, poor knowledge of local resistance rates, financial incentives for certain antibiotics and lack of legal consequences for incorrect antibiotic prescribing $(23,24)$. The government needs to try and tackle unregulated antibiotic use in the private sectors but this will be challenging given prescribing laws are often ignored and difficult to implement (19). Strategies could be targeted at educating and raising awareness about antimicrobial resistance amongst these healthcare professionals.

\section{Limitations}

As with all cross-sectional studies, the DHS data is at risk of recall bias, although non-response and selection bias was minimised by weighted data. Our analysis provides insight into the associations of demographic and behavioural variables with disease prevalence and antibiotic use but a causal relationship between exposure and outcome cannot be established, since the time sequence between exposure and outcome is not clear. Small sample subset sizes made it difficult to examine certain associations, in particular the impact of maternal smoking and breastfeeding on illness and antibiotic use. 2016 data was collected later in the year compared to 2006 and 2011 perhaps reflecting the disruption from the April 2015 earthquake. This seasonal variation along with the effect of the earthquake may have influenced trends in disease prevalence and make the 2016 data less comparable. Lastly, the data only provided a limited perspective on the 'appropriate' use of antibiotics, as neither clinical information nor microbiology results were available.

\section{Conclusion}

The results of our study highlight the importance of the following specific primary strategies that were proposed in the Situation Analysis conducted with the Global Antibiotic Resistance Partnership to improve antibiotic use: reduce the need for antibiotics by improving public health (in particular sanitation, nutrition and reduced indoor air pollution), rationalize antibiotic use in the community and educate health professionals, policy makers and the public on sustainable antibiotic use (7). These measures need to be balanced with ensuring those who need antibiotics the most can still access them. 
medRxiv preprint doi: https://doi.org/10.1101/2020.07.08.20149153; this version posted July 10, 2020. The copyright holder for this preprint

(which was not certified by peer review) is the author/funder, who has granted medRxiv a license to display the preprint in perpetuity. It is made available under a CC-BY-ND 4.0 International license .

\section{References}

1. Klein EY, Van Boeckel TP, Martinez EM, Pant S, Gandra S, Levin SA, et al. Global increase and geographic convergence in antibiotic consumption between 2000 and 2015. Proc Natl Acad Sci U S A. 2018;115(15):E3463-e70.

2. The World Health Organisation (WHO). WHO factsheet. Children: reducing mortality.; 2018.

3. Government of Nepal. Ministry of Finance. Economic Survey 2017/18. Singha Durbar, Kathmandu.

4. Muzzini, E. and Aparicio, G. Urban Growth and Spatial Transition in Nepal. Washington D.C.:

World Bank. 2013.

5. The World Bank. Poverty and Equity Data Portal - Nepal. URL http://povertydata.worldbank.org/poverty/country/NPL.

6. UN Inter-agency Group for Child Mortality Estimation ( UNICEF, WHO, World Bank, UN DESA Population Division ) at childmortality.org.

7. Basnyat B. Situation analysis and recommendations: antibiotic use and resistance in Nepal.: The Global antibiotic resistance partnership - Nepal national working group; 2015.

8. Ministry of Health Nepal. New E.R.A Nepal; Nepal Health Sector Support Program (NHSSP); and ICF.

2017. Nepal Health Facility Survey 2015. Kathmandu, Nepal: Ministry of Health, Nepal.

9. Ministry of Health and Population Nepal. New E. R. A. Nepal. Macro. International. Nepal Demographic And Health Survey 2006.

10. Ministry of Health and Population Nepal. New E. R. A. Nepal. I. C. F. International. Nepal Demographic and Health Survey 2011.

11. Ministry of Health Nepal. New E. R. A. Nepal. Icf. Nepal Demographic and Health Survey 2016.

12. Victora CG, Joseph G, Silva ICM, Maia FS, Vaughan JP, Barros FC, et al. The Inverse Equity Hypothesis:

Analyses of Institutional Deliveries in 286 National Surveys. Am J Public Health. 2018;108(4):464-71.

13. Gordon SB, Bruce NG, Grigg J, Hibberd PL, Kurmi OP, Lam KB, et al. Respiratory risks from household air pollution in low and middle income countries. Lancet Respir Med. 2014;2(10):823-60.

14. Bawankule R, Singh A, Kumar K, Shetye S. Does Measles Vaccination Reduce the Risk of Acute Respiratory Infection (ARI) and Diarrhea in Children: A Multi-Country Study? PLoS One. 2017;12(1):e0169713.

15. Welaga P, Hodgson A, Debpuur C, Aaby P, Binka F, Azongo D, et al. Measles Vaccination Supports Millennium Development Goal 4: Increasing Coverage and Increasing Child Survival in Northern Ghana, 1996-2012. Front Public Health. 2018;6:28.

16. Sorup S, Benn CS, Poulsen A, Krause TG, Aaby P, Ravn H. Live vaccine against measles, mumps, and rubella and the risk of hospital admissions for nontargeted infections. Jama. 2014;311(8):826-35.

17. Institute for Health Metrics and Evaluation (IHME). Findings from the Global Burden

of Disease Study 2017. Seattle, WA: IHME, 2018.

18. Fink G, D'Acremont $\mathrm{V}$, Leslie $\mathrm{HH}$, Cohen J. Antibiotic exposure among children younger than 5 years in lowincome and middle-income countries: a cross-sectional study of nationally representative facility-based and household-based surveys. Lancet Infect Dis. 2020;20(2):179-87.

19. Wachter DA, Joshi MP, Rimal B. Antibiotic dispensing by drug retailers in Kathmandu, Nepal. Trop Med Int Health. 1999;4(11):782-8.

20. Diwan V, Sabde YD, Bystrom E, De Costa A. Treatment of pediatric diarrhea: a simulated client study at private pharmacies of Ujjain, Madhya Pradesh, India. J Infect Dev Ctries. 2015;9(5):505-11.

21. Saengcharoen W, Lerkiatbundit S. Practice and attitudes regarding the management of childhood diarrhoea among pharmacies in Thailand. Int J Pharm Pract. 2010;18(6):323-31.

22. Rogawski ET, Platts-Mills JA, Seidman JC, John S, Mahfuz M, Ulak M, et al. Use of antibiotics in children younger than two years in eight countries: a prospective cohort study. Bull World Health Organ. 2017;95(1):49-61.

23. Ayukekbong JA, Ntemgwa M, Atabe AN. The threat of antimicrobial resistance in developing countries: causes and control strategies. Antimicrob Resist Infect Control. 2017;6:47.

24. Tangcharoensathien V, Chanvatik S, Sommanustweechai A. Complex determinants of inappropriate use of antibiotics. Bull World Health Organ. 2018;96(2):141-4. 
medRxiv preprint doi: https://doi.org/10.1101/2020.07.08.20149153; this version posted July 10, 2020. The copyright holder for this preprint (which was not certified by peer review) is the author/funder, who has granted medRxiv a license to display the preprint in perpetuity.

It is made available under a CC-BY-ND 4.0 International license.

\section{TABLES}

Table 1 Background characteristics of U5s alive at the time of the survey. Numbers represent weighted numbers in each category to enable comparison between years.

\begin{tabular}{|c|c|c|c|}
\hline & 2006 & 2011 & 2016 \\
\hline U5 population & 5252 & 5140 & 4887 \\
\hline $\begin{array}{l}\text { Male } \\
\text { Female }\end{array}$ & $\begin{array}{l}2681(51.0 \%) \\
2571(49.0 \%)\end{array}$ & $\begin{array}{l}2649(51.5 \%) \\
2490(48.4 \%)\end{array}$ & $\begin{array}{l}2563(52.4 \%) \\
2324(47.6 \%)\end{array}$ \\
\hline $\begin{array}{l}\text { Age (months) } \\
<6 \\
6-11 \\
12-23 \\
24-35 \\
36-47 \\
48-59\end{array}$ & $\begin{array}{l}484(9.2 \%) \\
494(9.4 \%) \\
984(18.7 \%) \\
1147(21.8 \%) \\
1049(20.0 \%) \\
1094(20.8 \%)\end{array}$ & $\begin{array}{l}531(10.3 \%) \\
491(9.1 \%) \\
1000(19.4 \%) \\
1013(19.7 \%) \\
1106(21.5 \%) \\
999(19.4 \%)\end{array}$ & $\begin{array}{l}423(8.7 \%) \\
476(9.7 \%) \\
1029(21.1 \%) \\
928(19.0 \%) \\
970(19.8 \%) \\
106021.7 \%)\end{array}$ \\
\hline $\begin{array}{l}\text { Urban } \\
\text { Rural }\end{array}$ & $\begin{array}{l}652(12.4 \%) \\
4600(87.6 \%)\end{array}$ & $\begin{array}{l}483(9.4 \%) \\
4656(90.1 \%)\end{array}$ & $\begin{array}{l}2649(54.2 \%) \\
2238(45.8 \%)\end{array}$ \\
\hline $\begin{array}{l}\text { Mountain } \\
\text { Hill } \\
\text { Terai }\end{array}$ & $\begin{array}{l}443(8.4 \%) \\
2171(41.3 \% \\
2638(50.2 \%)\end{array}$ & $\begin{array}{l}400(7.8 \%) \\
2033(39.6 \%) \\
2707(52.7 \%)\end{array}$ & $\begin{array}{l}342(7.0 \%) \\
1857(38.0 \%) \\
2688(55.0 \%)\end{array}$ \\
\hline $\begin{array}{l}\text { Wealth index } \\
\text { Poorest } \\
\text { Second } \\
\text { Middle } \\
\text { Fourth } \\
\text { Richest }\end{array}$ & $\begin{array}{l}1328(25.3 \%) \\
1117(21.3 \%) \\
1053(20.0 \%) \\
950(18.1 \%) \\
804(15.3 \%)\end{array}$ & $\begin{array}{l}1322(25.7 \%) \\
1212(23.6 \%) \\
1071(20.8 \%) \\
899(17.5 \%) \\
726(14.1 \%)\end{array}$ & $\begin{array}{l}1041(21.3 \%) \\
1028(21.0 \%) \\
1087(22.2 \%) \\
999(20.4 \%) \\
732(15.0 \%)\end{array}$ \\
\hline $\begin{array}{l}\text { Mother's education } \\
\text { No education } \\
\text { Primary } \\
\text { Secondary } \\
\text { Higher }\end{array}$ & $\begin{array}{l}3129(59.6 \%) \\
957(18.2 \%) \\
1038(19.8 \%) \\
128(2.4 \%)\end{array}$ & $\begin{array}{l}2410(46.9 \%) \\
1032(20.1 \%) \\
1411(27.5 \%) \\
287(5.6 \%)\end{array}$ & $\begin{array}{l}1663(34.0 \%) \\
981(20.1 \%) \\
1564(32.0 \%) \\
679(13.9 \%)\end{array}$ \\
\hline
\end{tabular}

Table 2 Demographic and behavioural determinants of disease (2016 data)

\begin{tabular}{|c|c|c|c|c|}
\hline Variable & Illness & $\begin{array}{l}\text { \% with } \\
\text { illness (n) }\end{array}$ & $\begin{array}{l}\text { Univariate } \\
\text { Odds Ratio (95\%Cl) }\end{array}$ & $\begin{array}{l}\text { Adjusted* } \\
\text { Odds Ratio }(95 \% \mathrm{Cl})\end{array}$ \\
\hline $\begin{array}{l}\text { Age: } \\
<6 \text { months } \\
6-11 \text { months } \\
12-23 \text { months } \\
24-35 \text { months } \\
36-47 \text { months } \\
48-59 \text { months }\end{array}$ & ARI & $\begin{array}{l}1.3(5) \\
4.5(21) \\
4.0(41) \\
2.2(20) \\
1.3(13) \\
1.6(17)\end{array}$ & $\begin{array}{l}3.59(1.40-9.26) \\
\mathbf{3 . 1 6}(1.28-7.79) \\
1.71(0.67-4.41) \\
1.01(0.38-2.71) \\
1.28(0.49-3.32)\end{array}$ & \\
\hline $\begin{array}{l}<6 \text { months } \\
6-11 \text { months } \\
12-23 \text { months } \\
24-35 \text { months } \\
36-47 \text { months }\end{array}$ & Fever & $\begin{array}{l}16.2(69) \\
29.0(138) \\
24.8(255) \\
21.7(202) \\
18.3(178)\end{array}$ & $\begin{array}{l}\mathbf{2 . 1 0}(1.45-3.05) \\
\mathbf{1 . 7 0}(1.19-2.43) \\
1.43(1.00-2.04) \\
1.16(0.82-1.62) \\
1.15(0.78-1.71)\end{array}$ & \\
\hline
\end{tabular}


medRxiv preprint doi: https://doi.org/10.1101/2020.07.08.20149153; this version posted July 10, 2020. The copyright holder for this preprint (which was not certified by peer review) is the author/funder, who has granted medRxiv a license to display the preprint in perpetuity.

It is made available under a CC-BY-ND 4.0 International license .

\begin{tabular}{|c|c|c|c|}
\hline $\begin{array}{l}\text { 48-59 months } \\
<6 \text { months } \\
6-11 \text { months } \\
12-23 \text { months } \\
24-35 \text { months } \\
36-47 \text { months } \\
48-59 \text { months }\end{array}$ & Diarrhoea & $\begin{array}{l}18.3(193) \\
6.0(25) \\
13.7(65) \\
10.9(112) \\
6.5(60) \\
6.3(61) \\
4.5(48)\end{array}$ & $\begin{array}{l}2.49(1.45-4.29) \\
1.93(1.19-3.15) \\
1.09(0.68-1.74) \\
1.06(0.63-1.80) \\
0.74(0.45-1.21)\end{array}$ \\
\hline $\begin{array}{l}\text { Urban } \\
\text { Rural } \\
\text { Urban } \\
\text { Rural } \\
\text { Urban } \\
\text { Rural }\end{array}$ & $\begin{array}{l}\text { ARI } \\
\text { Fever } \\
\text { Diarrhoea }\end{array}$ & $\begin{array}{l}2.1(55) \\
2.8(63) \\
\\
22.7(600) \\
19.4(434) \\
7.8(207) \\
7.4(165)\end{array}$ & $\begin{array}{l}1.36(0.90-2.07) \\
0.82(0.66-1.02) \\
0.94(0.66-1.34)\end{array}$ \\
\hline $\begin{array}{l}\text { Mountain } \\
\text { Hill } \\
\text { Terai } \\
\text { Mountain } \\
\text { Hill } \\
\text { Terai } \\
\text { Mountain } \\
\text { Hill } \\
\text { Terai }\end{array}$ & $\begin{array}{l}\text { ARI } \\
\text { Fever } \\
\text { Diarrhoea }\end{array}$ & $\begin{array}{l}2.9(10) \\
3.4(62) \\
1.7(46) \\
\\
16.4(56) \\
21.6(402) \\
21.4(576) \\
\\
5.2(18) \\
6.4(120) \\
8.7(234)\end{array}$ & $\begin{array}{l}1.17(0.64-2.12) \\
0.58(0.32-1.06) \\
1.40(0.97-2.02) \\
1.38(0.97-1.98) \\
1.26(0.73-2.16) \\
1.74(1.15-6.65)\end{array}$ \\
\hline $\begin{array}{l}\text { Wealth index } \\
\text { Poorest } \\
\text { Second } \\
\text { Middle } \\
\text { Fourth } \\
\text { Richest } \\
\text { Poorest } \\
\text { Second } \\
\text { Middle } \\
\text { Fourth } \\
\text { Richest } \\
\\
\text { Poorest } \\
\text { Second } \\
\text { Middle } \\
\text { Fourth } \\
\text { Richest }\end{array}$ & $\begin{array}{l}\text { ARI } \\
\text { Fever } \\
\text { Diarrhoea }\end{array}$ & $\begin{array}{l}3.3(34) \\
3.1(32) \\
2.4(26) \\
2.1(20) \\
0.6(4) \\
\\
17.9(186) \\
21.4(220) \\
23.0(251) \\
21.3(213) \\
22.5(164) \\
\\
5.9(61) \\
8.0(82) \\
8.4(91) \\
8.3(83) \\
7.3(54\end{array}$ & $\begin{array}{l}0.94(0.57-1.56) \\
0.73(0.38-1.38) \\
0.61(0.34-1.10) \\
\mathbf{0 . 1 7}(0.06-0.47) \\
\\
1.25(0.99-1.59) \\
\mathbf{1 . 3 8}(1.06-1.79) \\
1.25(0.95-1.64) \\
1.33(0.97-1.83) \\
\\
1.40(0.95-2.05) \\
1.46(0.96-2.24) \\
\mathbf{1 . 4 6}(1.02-2.09) \\
1.26(0.70-2.28)\end{array}$ \\
\hline $\begin{array}{l}\text { Maternal education: } \\
\text { No education } \\
\text { Primary education } \\
\text { Secondary/higher } \\
\text { No education } \\
\text { Primary education } \\
\text { Secondary/higher }\end{array}$ & ARI & $\begin{array}{l}2.1(35) \\
2.8(28) \\
2.5(55) \\
19.7(327) \\
21.5(211) \\
22.1(496)\end{array}$ & $\begin{array}{l}1.34(0.77-2.33) \\
1.16(0.72-1.87) \\
1.12(0.87-1.44) \\
1.16(0.93-1.44)\end{array}$ \\
\hline
\end{tabular}


medRxiv preprint doi: https://doi.org/10.1101/2020.07.08.20149153; this version posted July 10, 2020. The copyright holder for this preprint (which was not certified by peer review) is the author/funder, who has granted medRxiv a license to display the preprint in perpetuity.

It is made available under a CC-BY-ND 4.0 International license .

\begin{tabular}{|c|c|c|c|c|}
\hline $\begin{array}{l}\text { No education } \\
\text { Primary education } \\
\text { Secondary/higher }\end{array}$ & Diarrhoea & $\begin{array}{l}8.5(142) \\
8.4(82) \\
6.6(148)\end{array}$ & $\begin{array}{l}0.98(0.73-1.32) \\
0.76(0.55-1.05)\end{array}$ & \\
\hline Received measles vaccine & $\begin{array}{l}\text { ARI } \\
\text { Fever } \\
\text { Diarrhoea }\end{array}$ & $\begin{array}{l}3.4(68) \\
23.2(463) \\
8.5(169)\end{array}$ & $\begin{array}{l}1.49(0.88-2.51) \\
0.99(0.79-1.22) \\
0.78(0.55-1.11)\end{array}$ & $\begin{array}{l}1.67(0.84-3.31) \\
0.79(0.59-1.05) \\
0.64(0.34-1.18)\end{array}$ \\
\hline All basic vaccinations & $\begin{array}{l}\text { ARI } \\
\text { Fever } \\
\text { Diarrhoea }\end{array}$ & $\begin{array}{l}3.4(57) \\
23.0(394) \\
8.3(141)\end{array}$ & $\begin{array}{l}1.25(0.77-2.03) \\
0.96(0.78-1.19) \\
0.77(0.52-1.15)\end{array}$ & $\begin{array}{l}1.21(0.65-2.26) \\
0.84(0.65-1.09) \\
0.69(0.41-1.17)\end{array}$ \\
\hline Clean fuel & ARI & $1.4(16)$ & $\mathbf{0 . 4 8}(0.28-0.84)$ & $0.98(0.53-1.81)$ \\
\hline Maternal smoking & ARI & $4.3(8)$ & $1.86(0.73-4.74)$ & $1.61(0.60-4.30)$ \\
\hline Improved toilet sanitation & Diarrhoea & $6.7(231)$ & $0.68(0.46-1.00)$ & $0.66(0.42-1.03)$ \\
\hline Improved water source & Diarrhoea & $7.3(315)$ & $0.99(0.55-1.75)$ & $0.91(0.50-1.63)$ \\
\hline Wasting & $\begin{array}{l}\text { ARI } \\
\text { Fever } \\
\text { Diarrhoea }\end{array}$ & $\begin{array}{l}2.9(6) \\
28.5(61) \\
9.9(21)\end{array}$ & $\begin{array}{l}1.16(0.53-2.54) \\
1.56(1.08-2.24) \\
1.40(0.77-2.55)\end{array}$ & $\begin{array}{l}0.95(0.43-2.11) \\
1.54(1.07-2.23) \\
1.13(0.61-2.07)\end{array}$ \\
\hline Difficult access to healthcare & $\begin{array}{l}\text { ARI } \\
\text { Fever } \\
\text { Diarrhoea }\end{array}$ & $\begin{array}{l}2.9(86) \\
22.8(670) \\
9.1(266)\end{array}$ & $\begin{array}{l}\mathbf{1 . 8 1}(1.16-2.82) \\
\mathbf{1 . 2 9}(1.06-1.57) \\
\mathbf{1 . 7 5}(1.33-2.32)\end{array}$ & $\begin{array}{l}1.44(0.91-2.28) \\
\mathbf{1 . 4 4}(1.17-1.76) \\
\mathbf{1 . 9 5}(1.45-2.62)\end{array}$ \\
\hline \multicolumn{5}{|c|}{$\begin{array}{l}\text { *Variables in adjusted analysis - age, wealth index, urban/rural location } \\
\text { Wealth index - wealth quintile of household as determined by ownership of selected assets } \\
\text { All basic vaccinations - includes BCG, } 3 \times D P T, 3 X \text { Polio, Measles } \\
\text { Clean fuel - gas, kerosene, electric. Unclean fuel - wood, charcoal, animal dung, straw, agricultural crop } \\
\text { Improved toilet sanitation - sewer system, septic tank, VIP, covered pit, composting toilet. Unimproved toilet } \\
\text { sanitation - no facility/bush/field, open pit, pit latrine without slab, flush to unknown place } \\
\text { Improved water source - piped, public tap, tube well or borehole, protected well, protected spring or bottled water } \\
\text { Wasting - weight for height less than } 2 \text { s.d. of median } \\
\text { Difficult access to healthcare - distance to health facility is a problem for getting medical advice and treatment }\end{array}$} \\
\hline
\end{tabular}

Table 3 Demographic and behavioural determinants of antibiotic use (2016 data)

\begin{tabular}{|c|c|c|c|c|}
\hline Variable & Illness & $\begin{array}{c}\% \text { antibiotic } \\
\text { use }(n)^{* *}\end{array}$ & $\begin{array}{l}\text { Univariate } \\
\text { Odds Ratio }(95 \% \mathrm{Cl})\end{array}$ & $\begin{array}{l}\text { Adjusted* } \\
\text { Odds Ratio }(95 \% \mathrm{Cl})\end{array}$ \\
\hline Age: & ARI & & & \\
\hline$<6$ months & & $0.8(3)$ & & \\
\hline 6-11 months & & $2.3(11)$ & $2.93(0.71-12.09)$ & \\
\hline 12-23 months & & $1.6(17)$ & $2.08(0.55-7.90)$ & \\
\hline 24-35 months & & $0.7(6)$ & $0.89(0.20-3.90)$ & \\
\hline $36-47$ months & & $0.5(5)$ & $0.68(0.15-3.12)$ & \\
\hline 48-59 months & & $0.5(6)$ & $0.69(0.16-2.97)$ & \\
\hline$<6$ months & Fever & $4.7(20)$ & & \\
\hline 6-11 months & & $11.3(54)$ & $2.60(1.36-4.99)$ & \\
\hline 12-23 months & & $8.7(90)$ & $1.95(1.05-3.62)$ & \\
\hline 24-35 months & & $7.5(70)$ & $1.66(0.90-3.05)$ & \\
\hline 36-47 months & & $6.3(61)$ & $1.37(0.75-2.50)$ & \\
\hline 48-59 months & & $6.0(64)$ & $1.31(0.67-2.53)$ & \\
\hline
\end{tabular}


medRxiv preprint doi: https://doi.org/10.1101/2020.07.08.20149153; this version posted July 10, 2020. The copyright holder for this preprint (which was not certified by peer review) is the author/funder, who has granted medRxiv a license to display the preprint in perpetuity.

It is made available under a CC-BY-ND 4.0 International license .

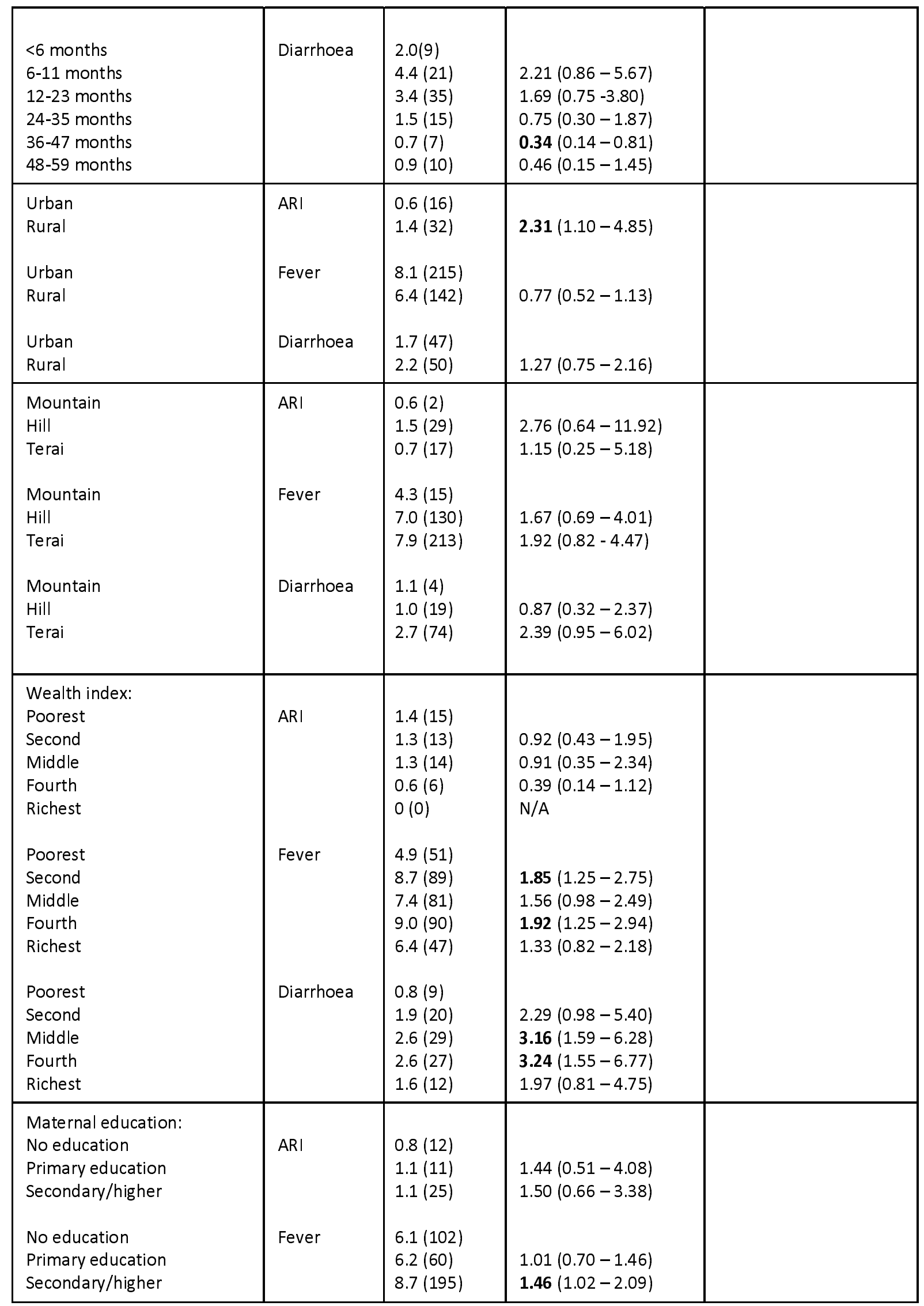


medRxiv preprint doi: https://doi.org/10.1101/2020.07.08.20149153; this version posted July 10, 2020. The copyright holder for this preprint (which was not certified by peer review) is the author/funder, who has granted medRxiv a license to display the preprint in perpetuity.

It is made available under a CC-BY-ND 4.0 International license .

\begin{tabular}{|c|c|c|c|c|}
\hline $\begin{array}{l}\text { No education } \\
\text { Primary education } \\
\text { Secondary/higher }\end{array}$ & Diarrhoea & $\begin{array}{l}2.2(38) \\
2.2(22) \\
1.6(37)\end{array}$ & $\begin{array}{l}1.01(0.57-1.76) \\
0.75(0.42-1.32)\end{array}$ & \\
\hline Received measles vaccine & $\begin{array}{l}\text { ARI } \\
\text { Fever } \\
\text { Diarrhoea }\end{array}$ & $\begin{array}{l}1.3(27) \\
7.8(156) \\
2.2(44)\end{array}$ & $\begin{array}{l}1.16(0.51-2.62) \\
0.88(0.63-1.21) \\
0.55(0.33-0.91)\end{array}$ & $\begin{array}{l}1.98(0.81-4.86) \\
0.62(0.35-1.12) \\
\mathbf{0 . 4 1}(0.18-0.95)\end{array}$ \\
\hline All basic vaccinations & $\begin{array}{l}\text { ARI } \\
\text { Fever } \\
\text { Diarrhoea }\end{array}$ & $\begin{array}{l}1.4(24) \\
7.8(133) \\
2.0(34)\end{array}$ & $\begin{array}{l}1.25(0.55-2.86) \\
0.89(0.66-1.19) \\
\mathbf{0 . 5 1}(0.32-0.82)\end{array}$ & $\begin{array}{l}1.88(0.79-4.47) \\
0.75(0.53-1.06) \\
\mathbf{0 . 4 3}(0.25-0.76)\end{array}$ \\
\hline Clean fuel & ARI & $0.3(3)$ & $0.22(0.07-0.71)$ & $0.71(0.22-2.26)$ \\
\hline Maternal smoking & ARI & $1.8(3)$ & $1.95(0.31-12.50)$ & $1.73(0.24-12.70)$ \\
\hline Improved toilet sanitation & Diarrhoea & $1.6(56)$ & $0.57(0.31-1.07)$ & $0.59(0.72-5.99)$ \\
\hline Improved water source & Diarrhoea & $1.8(82)$ & $0.96(0.30-3.09)$ & $1.92(0.40-9.16)$ \\
\hline Wasting & $\begin{array}{l}\text { ARI } \\
\text { Fever } \\
\text { Diarrhoea }\end{array}$ & $\begin{array}{l}0.4(1) \\
10.7(23) \\
4.2(9)\end{array}$ & $\begin{array}{l}0.36(0.05-2.76) \\
1.64(0.98-2.74) \\
\mathbf{2 . 7 6}(1.04-7.29)\end{array}$ & $\begin{array}{l}0.26(0.03-2.06) \\
1.52(0.93-2.51) \\
2.29(0.87-6.03)\end{array}$ \\
\hline Difficult access to healthcare & $\begin{array}{l}\text { ARI } \\
\text { Fever } \\
\text { Diarrhoea }\end{array}$ & $\begin{array}{l}(33) \\
8.1(239) \\
2.3(70)\end{array}$ & $\begin{array}{l}1.46(0.71-3.00) \\
1.14(0.79-1.65) \\
1.73(0.98-3.04)\end{array}$ & $\begin{array}{l}1.00(0.48-2.08) \\
1.52(1.10-2.09) \\
1.93(1.09-3.43)\end{array}$ \\
\hline \multicolumn{5}{|c|}{$\begin{array}{l}\text { *Variables in adjusted analysis - age, wealth index, urban/rural location } \\
\text { **Antibiotic use is expressed as a percentage of the total population i.e. those with and without illness } \\
\text { Wealth index - wealth quintile of household as determined by ownership of selected assets } \\
\text { All basic vaccinations -includes BCG, 3XDPT, 3X Polio, Measles } \\
\text { Clean fuel - gas, kerosene, electric. Unclean fuel - wood, charcoal, animal dung, straw, agricultural crop } \\
\text { Improved toilet sanitation - sewer system, septic tank, VIP, covered pit, composting toilet. Unimproved toilet } \\
\text { sanitation - no facility/bush/field, open pit, pit latrine without slab, flush to unknown place } \\
\text { Improved water source - piped, public tap, tube well or borehole, protected well, protected spring or bottled water } \\
\text { Wasting - weight for height less than } 2 \text { s.d. of median } \\
\text { Difficult access to healthcare - distance to health facility is a problem for getting medical advice and treatment }\end{array}$} \\
\hline
\end{tabular}


Figure 1 Demographic determinants of disease prevalence from 2006-2016

A. Overall disease prevalence from $2006-2016$

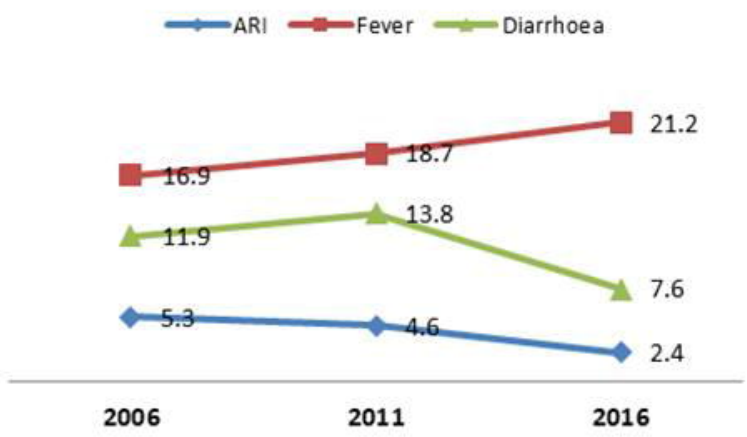

C. Percentage prevalence of ARI by ecological zone from 2006 - 2016

mountain $\quad$ Hill $=$ Terai

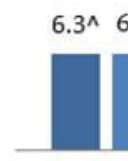
2006
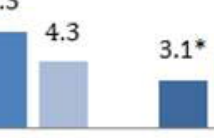

2011
$5.2 \quad 4.5$
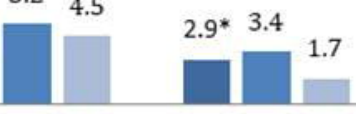

2016
B. Reported prevalence of ARI by wealth index from 2006-2016

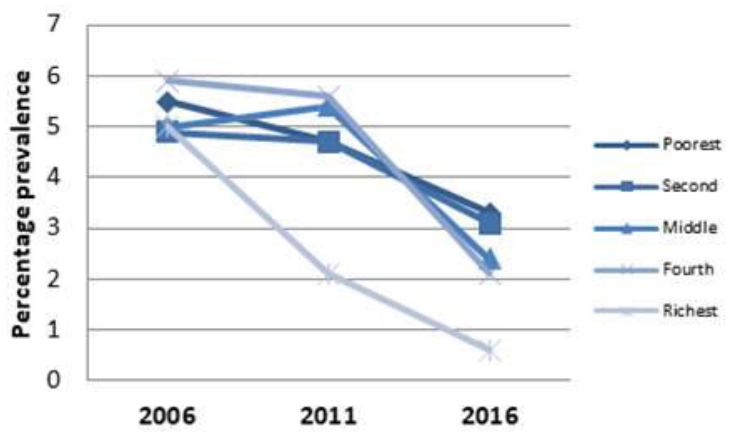

D. Percentage prevalence of diarrhoea by ecological zone from 2006 - 2016
nill
Terai

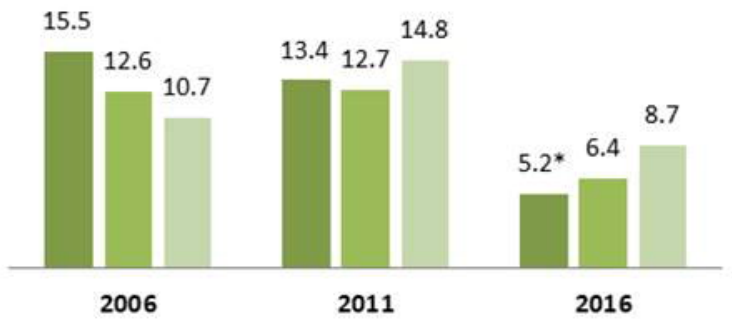

* estimates are based on fewer than 25 cases

$\wedge$ estimates are based on 25-29 cases 
Figure 2. Determinants of antibiotic consumption for ARI, fever and diarrhoea from 2006 - 2016

A. Overall percentage of antibiotic use in the disease population 2006 - 2016

$\longrightarrow$ ARI - Fever $\longrightarrow$ Diarrhoea

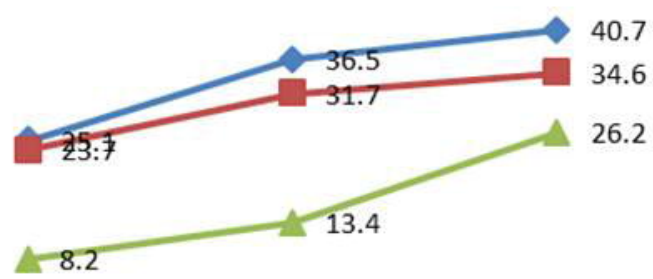

2006

2011

2016
B. Percentage of children with ARI receiving antibiotics by wealth quintile 2006-2016

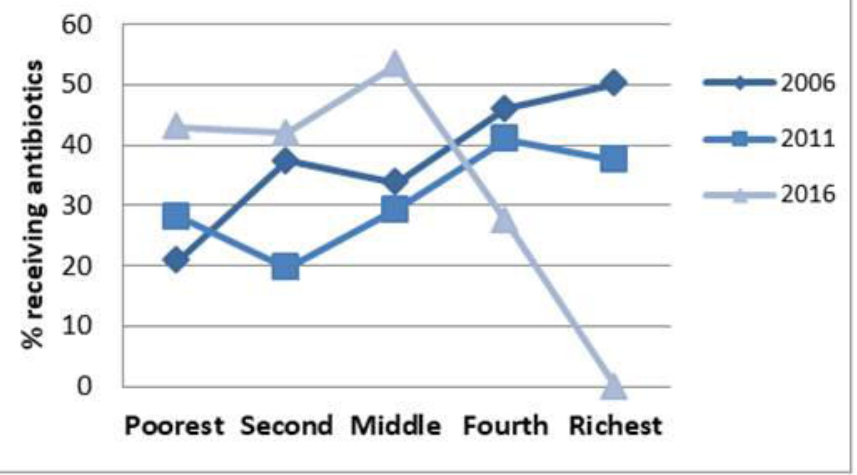

C. Urban and rural rates of antibiotic consumption for ARI, fever and diarrhoea from $2006-2016$

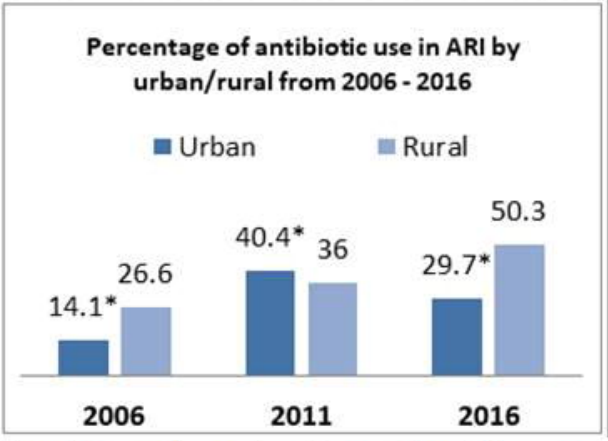

Percentage of antibiotic use in fever by urban/rural from 2006 - 2016

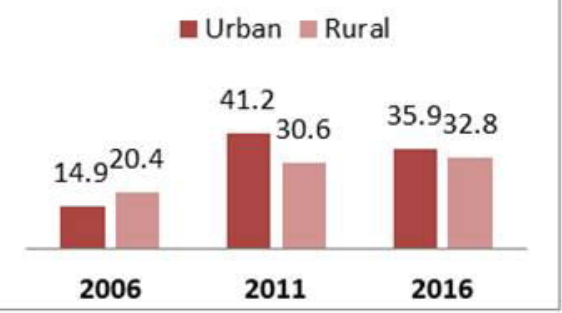

Percentage of antibiotic use in diarrhoea by urban/rural from 2006 $-2016$

Erban $\quad$ Rural

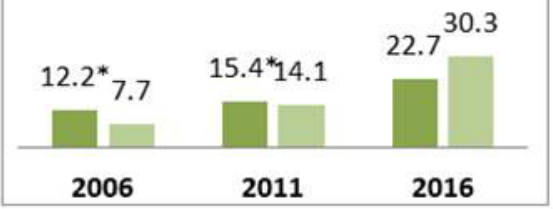

* estimates based on fewer than 25 cases 


\section{Figure 3}

A. Percentage of children with ARI, fever and diarrhoea who sought care by facility from 2006 -2016

\section{$\%$ of children with ARI}

[ 2006 =2011 2016

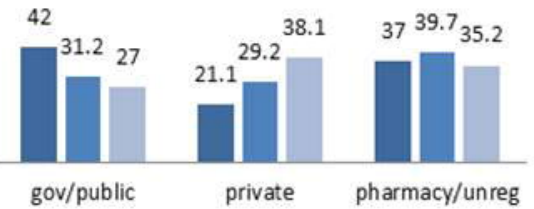

$\%$ children with fever

- $2006=2011=2016$

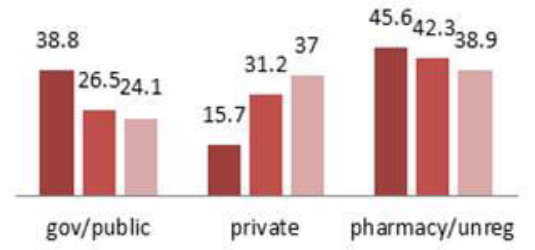

\section{$\%$ children with diarrhoea}

an $2006=2011=2016$

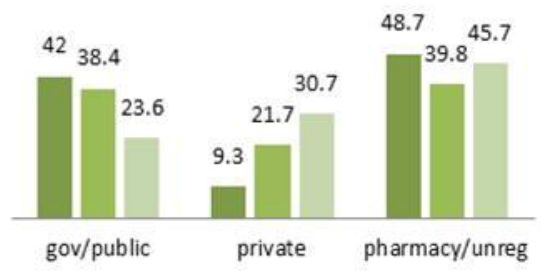

B. Percentage breakdown of children who sought care and received an antibiotic by facility from 2006 - 2016

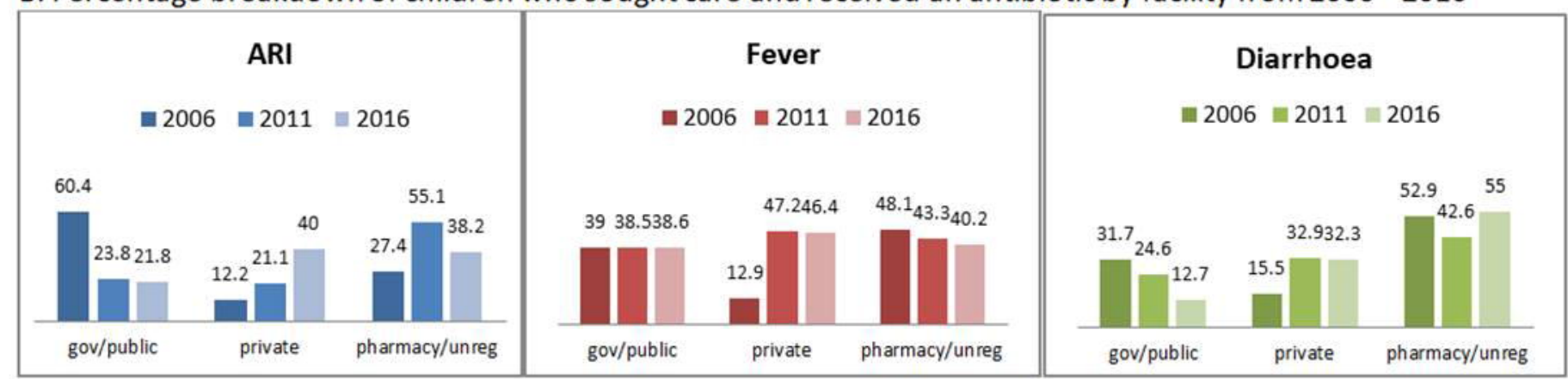

Government/public: government hospital, primary health care centre, health post/sub health post, primary healthcare outreach post, female community health volunteer, NGOs

Private: private hospital, private clinic, private doctor.

Pharmacy/unregulated:pharmacy, shop, traditional practitioner/healer 